\title{
Antimicrobial activity of Isothecium alopecuroides and potential effect of some climate elements on the activity of this bryophyte sample
}

\author{
Ergin Murat ALTUNER ${ }^{1 *}$, Barbaros ÇETIN ${ }^{2}$ \\ ${ }^{1}$ Kastamonu University, Faculty of Science and Arts, Department of Biology, Kastamonu, 37150, \\ TURKEY \\ ${ }^{2}$ Dokuz Eylül University, Faculty of Science, Department of Biology, İzmir, TURKEY \\ *Corresponding author: ergin.murat.altuner@gmail.com
}

Received Date: 24.05.2017

Accepted Date: 21.05.2018

\section{Abstract}

Aim of study: This study aims to present how some climate elements can dramatically affect the antimicrobial activity of a plant by using Isothecium alopecuroides (Lam. ex Dubois) Isov., a bryophyte, as a plant sample to put forward some important environmental factors.

Material and Methods: Two bryophyte samples, which were collected from two different locations, namely Aydın and Muğla. Chloroform, benzene, diethyl ether, ethyl alcohol, methyl alcohol, ethyl acetate, $\mathrm{sdH}_{2} \mathrm{O}$ and $0.5 \mathrm{M}$ Tris- $\mathrm{HCl}$ buffer $(\mathrm{pH}: 8.0)$ were used as extraction solvents. The antimicrobial activity were tested against Bacillus subtilis, Candida albicans, Escherichia coli, Listeria monocytogenes, Salmonella enteretidis, Shigella flexneri, Staphylococcus aureus and Yersinia enterocolitica by disk diffusion, minimum inhibitory concentration test and minimum bactericidal/fungicial concentration tests. Meteorological data were obtained from the Turkish State Meteorological Service.

Main results: As a result, it was observed that the bryophyte sample collected from Aydin was only active against $B$. subtilis with only its benzene extract, but the sample collected from Muğla was active against $B$. subtilis, $S$. aureus, $E$. coli and $C$. albicans with its different extracts at different ranges. Some climate elements were also found to be important in the activity of samples.

Research highlights: It is concluded that in any study based on secondary metabolites, the time and the environmental conditions, where the plant samples are collected should be taken into account.

Keywords: Isothecium alopecuroides, antimicrobial activity, climate, secondary metabolites, environmental factors.

\section{Isothecium alopecuroides'in antimikrobiyal aktivitesi ve bazı iklim elemanlarının bu briyofit örneğinin aktivitesi üzerine potansiyel etkisi}

\section{Özet}

Çalış̧manın amacı: Bu çalışmanın amacı, bir briyofit olan Isothecium alopecuroides (Lam. ex Dubois) Isov.'i örnek olarak kullanarak iklimin bir bitkinin antimikrobiyal aktivitesini nasıl önemli ölçüde etkileyebileceği göstermek ve araştırmacılar tarafından bitki örneklerini toplayabilecekleri doğru yeri ve zamanı belirlemek için dikkate alabilecekleri bazı önemli çevresel faktörleri ortaya koymaktır.

Materyal ve Yöntem: İki adet briyofit örneği Aydın ve Muğla olmak üzere iki farklı lokasyondan toplanmıştır. Ekstraksiyon çözücüsü olarak kloroform, benzen, dietil eter, etil alkol, metil alkol, etil asetat, $\mathrm{sdH}_{2} 0$ ve $0,5 \mathrm{M}$ Tris- $\mathrm{HCl}$ tamponu (pH: 8.0) kullanılmıştır. Antimikrobiyal aktivite Bacillus subtilis, Candida albicans, Escherichia coli, Listeria monocytogenes, Salmonella enteretidis, Shigella flexneri, Staphylococcus aureus ve Yersinia enterocolitica' ya karşı disk difüzyon, minimum inhibisyon konsantrasyonu ve minimum bakterisidal/fungisidal konsantrasyonu testleri ile denenmiştir. Meteorolojik veriler ise Meteoroloji İşleri Genel Müdürlüğü’nden alınmıştır.

Temel Sonuçlar: Sonuç olarak Aydın'dan toplanan briyofit örneğinin sadece benzen ekstraktının $B$. subtilis'e etki ettiği, Muğla'dan toplanan örneğin ise $B$. subtilis, S. aureus, E. coli ve C. albicans'a farklı ekstraktlarda farklı değerlerde etkili olduğu gözlenmiş̧tir. Bazı iklim elemanlarının da etkide önemli olduğu bulunmuştur.

Araştırma vurguları: Sekonder metabolitlere dayalı yapılacak herhangi bir çalışmada, bitki örneklerinin toplandığı zaman ve çevresel koşulların dikkate alınması gerektiği sonucuna varılmıştır.

Anahtar kelimeler: Isothecium alopecuroides, antimikrobiyal aktivite, iklim, sekonder metabolitler, çevresel faktörler

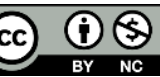




\section{Introduction}

Plants synthesize a wide range of compounds involved in their adaptation to their environment which can be classified as primary and secondary metabolites (Crozier et al., 2006). The primary metabolites synthesized through metabolic pathways are found in all plants, and they are essential for the plant's survival. These compounds are directly involved in the plant's growth, development and reproduction process. In contrast, the secondary metabolites are not essential for the functioning of the plant; they are important in the long term, and used for defence against herbivores and pathogens, regulation of symbiosis, control of seed germination, chemical inhibition of competing plant species and adaptation of plants to their environment (Jones, 1996; Croteau et al., 2000).

Several internal and external factors may influence the production of secondary metabolites and their composition as well. Climate is one of the environmental factors, out of human control, that could affect secondary metabolism; which brings us to consider in a research about new antiinfective medicinal agents before collecting plant samples (Cseke et al., 2016).

According to findings in several researches into secondary metabolites, some of the major plant secondary metabolites can be listed as protease inhibitors, lectins, alkaloids, non-protein amino acids, cyanogenic glycosides, saponins and tannins (Jones, 1996). These secondary metabolites from plants have been used for a wide variety of purposes for hundreds of years (Jones, 1996; Canl1 et al. 2015). In recent years, because of their wide range of effects, including antioxidant, antiviral, antibacterial and anticancer activities, interest has risen dramatically in research into secondary metabolites in plants (Makkar et al., 2007).

The antimicrobial activity of plants provided by their secondary metabolites has many applications, including raw and processed food preservation, pharmaceuticals, alternative medicine and natural therapies (Reynolds, 1996; LisBalchin and Deans, 1997). In contrast to the extensive utilisation of higher plants as a source of anti-microbial substances, bryophytes have rarely been considered for this (Basile et al., 1998).

It has been known for centuries that bryophytes are effective in both woundhealing processes and in lowering the risk of infections. In previous studies it has been presented that some secondary metabolites extracted from bryophytes have anti-infective effects on some bacteria and fungi (Veljic et al., 2008; Altuner and Çetin, 2009; Altuner and Çetin, 2010; Altuner et al., 2010b; Onbaş11 et al., 2011; Altuner and Canl1, 2012, Altuner et al., 2014; Canlı et al., 2014).

Several bryophyte samples were used by Chinese traditional medicine to treat cardiovascular diseases, tonsillitis, bronchitis, cystitis and skin infections. Native Americans used some bryophytes, such as Bryum, Mnium and Philonotis, to heal burns, bruises and wounds (Saroya, 2011).

Since drug resistance develops in human pathogens against commonly used antibiotics, there is a need for a search about new antimicrobial substances from other sources including plants (Erdogrul, 2002).

The time and the place for plant collection is very important in the search for new antimicrobial agents from plants, because several environmental factors, such as climate, may influence the production of secondary metabolites and their composition, as stated previously (Figueiredo et al., 2008).

This study aims to present how climate can dramatically affect the antimicrobial activity of a plant by using Isothecium alopecuroides, as a plant sample to put forward some important environmental factors, those should be taken into account by researchers to determine the right place and the right time for sample collection.

\section{Materials and Method Plant material}

Isothecium alopecuroides (Lam. ex Dubois) Isov. (IA) samples used in this study were collected and identified by Professor B. Çetin and Professor G. Uyar. Voucher specimens were deposited in personal collection of Professor B. Çetin for further reference. 
Two different $I A$ samples were collected from two different locations. Information about the locations, substrates and their altitudes are as follows:

- Isothecium alopecuroides (Dubois) Isov., Location: Aydın, Kuşadası, Turkey; Substrate: Rock; Altitude: 350 m. (IAA).

- Isothecium alopecuroides (Dubois) Isov., Location: Muğla, Köyceğiz, Dalyan, Turkey; Substrate: Soil; Altitude: $20 \mathrm{~m}$. $(I A-M)$.

\section{Extraction procedure}

Before beginning the extraction procedure, $I A-A$ and $I A-M$ samples were extensively washed with sterile distilled water $\left(\mathrm{sdH}_{2} \mathrm{O}\right)$. In order to reduce the particle size to ease the extraction procedure, samples were ground in a mortar and pestle after being treated with liquid nitrogen, and a fine powder was obtained for each sample by crushing the dry, frozen material (Canli et al., 2016). Ground samples were extracted subsequently with extraction solvents such as chloroform $(C H L)$, benzene $(B E)$, diethyl ether (DEE), ethyl alcohol (EtOH), methyl alcohol $(\mathrm{MeOH})$, ethyl acetate $(E A), \mathrm{sdH}_{2} \mathrm{O}$ and $0.5 \mathrm{M}$ Tris- $\mathrm{HCl}$ buffer (pH: 8.0). All solvents used in the study were purchased from Sigma-Aldrich, Germany. After 1 hour, all extracts were centrifuged at $4000 \mathrm{rpm}$ (Basile et al., 1998), and the supernatants were transferred into evaporation flasks and evaporated by a rotary evaporator and lyophilized after evaporation, if needed. 0.1 gr of remnants were dissolved in $2 \mathrm{~mL}$ of extraction solvents to prepare an extract stock of $50 \mathrm{mg} \cdot \mathrm{mL}^{-1}$.

\section{Microorganisms}

Bacillus subtilis ATCC 6633, Candida albicans ATCC 95071, Escherichia coli ATCC 11230, Escherichia coli O157:H7 Listeria monocytogenes ATCC 7644 Salmonella enteretidis ATCC 13076, Shigella flexneri (clinical isolate), Staphylococcus aureus ATCC 25923 and Yersinia enterocolitica $\mathrm{O} 3$ were used in the study (Ankara University, Faculty of Science, Department of Biology, Bacteriology Laboratory Culture Collection).

\section{Preparation of inocula}

All bacterial strains were incubated in atmospheric air at $37^{\circ} \mathrm{C}$ for 24 hours and $C$. albicans at $27^{\circ} \mathrm{C}$ for 48 hours. Inocula were prepared by transferring morphologically similar colonies of each organism into $0.9 \%$ sterile saline solution until the visible turbidity was equal to $0.5 \mathrm{McFarland}$ standard, having approximately $10^{8} \mathrm{cfu} . \mathrm{mL}^{-1}$ for bacteria and $10^{7}$ cfu. $\mathrm{mL}^{-1}$ for C. albicans (Hammer et al., 1999; Altuner and Akata, 2010). Nutrient Agar (HiMedia) medium was used for bacteria, where the C. albicans strain was inoculated on Potato Dextrose Agar (Oxoid).

\section{Disk diffusion method}

The disk diffusion test (DDT) was performed as described previously by Andrews (2003), with a modification. Nutrient Agar was poured into $120 \mathrm{~mm}$ sterile petri dishes to give a mean depth of $4.0 \mathrm{~mm} \pm 0.5 \mathrm{~mm}$ (Altuner and Çetin, 2009; Altuner and Çetin, 2010).

A $20 \mu \mathrm{L}$ of each extract was applied on sterile empty paper antibiotic disks with a 6 $\mathrm{mm}$ diameter (HiMedia). To get rid of any residual solvent which might interfere with the results, disks were left to dry overnight at $30{ }^{\circ} \mathrm{C}$ in sterile conditions (Altuner, 2011; Altuner et al., 2012a; 2012b).

The surface of the plates was inoculated using previously prepared inocula containing saline suspension of microorganisms. Inoculated plates were then left to dry for 5 minutes at room temperature before applying the disks. Disks were firmly applied to the surface of the agar plate, which had an even contact with the agar. Plates were incubated and inhibition zone diameters were expressed in millimetres.

\section{Determination of MIC}

Broth dilution method for minimum inhibitory concentration (MIC) determination as described in Basile et al. (1998) was employed with a modification.

Serial 2-fold dilutions were made to obtain a concentration range of $0.078-40$ $\mu 1 . \mathrm{mL}^{-1}$. The $M I C$ was defined as the lowest concentration of extract inhibiting any visible bacterial growth. 


\section{Determination of MBC and MFC}

The determinations of minimum bactericidal concentration $(M B C)$ and the minimum fungicidal concentration $(M F C)$ were performed by sub-culturing suspensions from non-turbid $M I C$ test tubes to Nutrient Agar plates. The $M B C$ and $M F C$ were defined as the lowest concentration of extracts inhibiting bacterial and fungal growth.

\section{Controls}

All extraction solvents and empty sterile disks were used as negative controls.

Six standard antibiotic disks containing cephalothin $(30 \mu \mathrm{g})$, gentamicin $(10 \mu \mathrm{g})$, cefuroxime $(30 \mu \mathrm{g})$, ampicilline $(10 \mu \mathrm{g})$, sulfamethoxazole - trimethoprim (23.75 $1.25 \mu \mathrm{g})$ and vancomycin $(30 \mu \mathrm{g})$ were used as positive control.

\section{Meteorological data}

Meteorological data were obtained from the Turkish State Meteorological Service. A wide range of meteorological data was obtained. The data having statistically significant differences were chosen for the study, which were:

- monthly average temperature

- monthly minimum/maximum temperature

- monthly maximum temperature difference in daytime

- number of days of monthly maximum temperature $\geq 30{ }^{\circ} \mathrm{C}$

- monthly average of free surface evaporation

- monthly average soil temperature at $5 \mathrm{~cm}$ and $10 \mathrm{~cm}$

- monthly average minimum/maximum soil temperature at $5 \mathrm{~cm}$ and $10 \mathrm{~cm}$

- monthly average number of days of temperature above soil $\leq-0.1{ }^{\circ} \mathrm{C}$

- average monthly precipitation

- average monthly humidity

- average monthly daily total global sunshine intensity

- monthly average daily total hours of sunshine.

\section{Statistics}

The data determined by $D D T, M I C$ and $M B C / M F C$ are given as the mean of 3 parallel studies. All values given here are the mean values of these 3 parallel studies.

The statistical analysis was performed by the Kruskal-Wallis one-way analysis of variance. $P$ values of $<0.05$ were considered statistically significant.

\section{Results}

The diameters of the inhibition zones, recorded in millimetres, are given in Table 1.

The $M I C, M B C$ and $M F C$ values stated as mg. $\mathrm{mL}^{-1}$, are given in Table 1 and the results of positive control disks are given in Table 2 .

According to the statistical analysis, there are no difference between parallel studies $(P$ $>0.05$ ).

In addition no activity were observed for negative controls.

To compare the effect of environmental factors on the antimicrobial activity of $I A$ samples collected from two different locations, the meteorological data for these two locations obtained from the Turkish State Meteorological Service about monthly temperature values are given in Figure 1, monthly soil temperature values in Figure 2 and monthly precipitation values, monthly humidity values and monthly average daily total global sunshine values in Figure 3.

\section{Discussion}

In this study it was observed that both $I A$ extractions, namely $I A-A$ and $I A-M$, showed antimicrobial activity to some extent. According to the results of the $D D T$ given in Table 1, it is possible to say that the $B E$ extracts of $I A-A$ has an antibacterial activity against $B$. subtilis, which is $12.00 \pm 0.00$ millimetres. Although the concentration of extracts loaded onto the sterile empty antibiotic disk is low, it shows an antibacterial effect close to that of sulfamethoxazole - trimethoprim on $B$. subtilis given in Table 2.

Unfortunately the $B E$ extracts of $I A-M$ showed no antibacterial effect against $B$. subtilis, as stated in Table 1. But the $\mathrm{MeOH}$ extracts of this bryophyte sample have an antibacterial effect against $B$. subtilis, which is $20.33 \pm 0.34$ millimetres. That is higher than the effect of the $B E$ extracts of $I A-A$. 
In addition, the $\mathrm{MeOH}$ and $\mathrm{EA}$ extracts of $I A$ $M$ have an antibacterial effect on $S$. aureus, which were both $8.00 \pm 0.00$ millimetres in the $D D T$ results given in Table 1 .

Table 1. Test results for $I A-A$ and $I A-M$. The diameters of the inhibition zones are recorded in millimetres. $M I C$ and $M B C / M F C$ values were given below as $\mathrm{mg} \cdot \mathrm{mL}^{-1}$.

\begin{tabular}{|c|c|c|c|c|c|c|c|c|c|c|}
\hline \multicolumn{2}{|l|}{$I A-A$} & & CHL & & $B E$ & $D E E$ & $\mathrm{EtOH}$ & $\mathrm{MeOH}$ & $\mathrm{sdH}_{2} \mathrm{O}$ & Buffer \\
\hline \multirow{3}{*}{\multicolumn{2}{|c|}{ B. subtilis }} & DDT & - & 12,0 & $\pm 0,00$ & - & - & - & - & - \\
\hline & & MIC & - & 10,0 & $\pm 0,00$ & - & - & - & - & - \\
\hline & & $\mathrm{MBC}$ & - & 10,0 & $\pm 0,00$ & - & - & - & - & - \\
\hline \multicolumn{2}{|l|}{$I A-M$} & CHL & $B$ & $E$ & $D E E$ & $\mathrm{EtOH}$ & $\mathrm{MeOH}$ & $E A$ & $\mathrm{sdH}_{2} \mathrm{O}$ & Buffer \\
\hline \multirow{3}{*}{ B. subtilis } & $\mathrm{DD}^{7}$ & - & & - & - & - & $20,33 \pm 0,3<$ & - & - & - \\
\hline & MIC & - & & - & - & - & $5,00 \pm 0,00$ & - & - & - \\
\hline & $\mathrm{MB}$ & - & & - & - & - & $5,00 \pm 0,00$ & - & - & - \\
\hline \multirow{3}{*}{ S. aureus } & DD & - & & - & - & - & $8,00 \pm 0,00$ & $8,00 \pm 0,00$ & 00 & - \\
\hline & MIC & - & & - & - & - & $40,00 \pm 0,0 C$ & $(40,00 \pm 0,0$ & $0 c$ & - \\
\hline & $\mathrm{MB}$ & - & & - & - & -7 & $>40,00 \pm 0,0>$ & $>40,00 \pm 0$ &, 0 & - \\
\hline \multirow{3}{*}{ E.coli } & $\mathrm{DD}^{7}$ & ] $7,33 \pm 0$ & ,34 9,00 & $\pm 0,0$ & $8,67 \pm 0,3<$ & - & - & - & $7,33 \pm 0,34$ & - \\
\hline & MIC & $C 40,00 \pm$ & $0,0(40,00$ & $0 \pm 0$ & $40,00 \pm 0,0$ & - & - & - & $40,00 \pm 0,0 \mathrm{C}$ & - \\
\hline & $\mathrm{MB}$ & $1>40,00 \pm$ & $0,040,00$ & \pm 0 & $40,00 \pm 0,0$ & - & - & - & $>40,00 \pm 0,0$ & - \\
\hline \multirow{3}{*}{ C. albicans } & $\mathrm{DD}^{-}$ & - & & - & - & - & - & - & $39,33 \pm 0,34$ & $9,00 \pm 0,0($ \\
\hline & MIC & - & & - & - & - & - & - & $0,625 \pm 0,0 \subset 4$ & $40,00 \pm 0,0$ \\
\hline & MFC & - & & - & - & - & - & - & $0,625 \pm 0,0 \subset 4$ & $40,00 \pm 0,0$ \\
\hline
\end{tabular}

“-” implies no effect.

Table 2. Positive control results. The diameters of the inhibition zones for the positive controls are given in millimetres below.

\begin{tabular}{lcccccc}
\hline & Cephalothin & Gentamicin & Cefuroxime & Ampicilline & $\begin{array}{c}\text { Sulfamethoxazole - } \\
\text { Trimethoprim }\end{array}$ & Vancomycin \\
\hline S. flexneri & 22,00 & 22,00 & 29,00 & - & 26,00 & 14,00 \\
B. subtilis & 56,00 & 44,00 & 40,00 & 32,00 & 22,00 & 32,00 \\
Y. enterocolitica & - & 23,00 & 24,00 & - & 25,00 & - \\
S. enteretidis & 22,00 & 24,00 & 12,00 & - & 22,00 & 19,00 \\
S. aureus & 56,00 & 27,00 & 44,00 & 54,00 & 27,00 & 23,00 \\
E. coli & 19,00 & 20,00 & 26,00 & 20,00 & 23,00 & 8,00 \\
C. albicans & - & 24,00 & - & 22,00 & - & 38,00 \\
E. coli & 18,00 & 22,00 & 24,00 & - & 17,00 & - \\
L. & 15,00 & 26,00 & 26,00 & 23,00 & 21,00 & 9,00 \\
\hline
\end{tabular}

"-" implies no effect.

These antibacterial effects are very low when compared with the positive control results given in Table 2. But increasing the amount of extracts loaded onto the sterile empty antibiotic disks could present higher antibacterial activity against $S$. aureus when compared to the positive control results.

The $C H L, B E, D E E$ and $\mathrm{sdH}_{2} \mathrm{O}$ extracts of $I A-M$ have presented very low antibacterial activity against $E$. coli: $7.33 \pm 0.34,9.00 \pm$ $0.00,8.67 \pm 0.34$ and $7.33 \pm 0.34$ millimetres 
respectively. Although these values are very low, they are still higher than the antibacterial effects of ampicillin and vancomycin against $E$. coli as given in Table 2. But, as stated previously, these values are lower than the antimicrobial effects of other standard antibiotic disks, namely cephalothin, gentamicin, sulfamethoxazole trimethoprim and cefuroxime.

The $\mathrm{sdH}_{2} \mathrm{O}$ and buffer extracts of $I A-M$ have presented antifungal effects against $C$. albicans, which are $39.33 \pm 0.34$ and $9.00 \pm$ 0.00 respectively, as given in Table 1 . When compared with the positive control results given in Table 2, the $\mathrm{sdH}_{2} \mathrm{O}$ extracts of $I A-M$ in particular have a relatively high antifungal effect against $C$. albicans. The antifungal effects of these extracts are very remarkable when compared to all positive control disk results.

Antimicrobial substances may have a lethal or static type of activity. Lethal agents have a capability of killing microorganisms, whereas static agents have a capability of inhibiting the growth or reproduction of microorganisms. The disk diffusion test alone is not enough to decide whether the activity is of a lethal or static type. In order to identify the type of activity, the disk diffusion test should be followed by $M I C$ and $M B C / M F C$ tests. Lethal agents have $M B C / M F C$ values that are close to the $M I C$ values. For static agents, the $M I C$ values are lower than the $M B C / M F C$ values.

If the $M I C$ and $M B C / M F C$ values given in Table 1 are compared it can be decided which extract has a lethal and which has a static type of activity. Since the $M I C$ values and $M B C$ values are the same in the $B E$ extracts of $I A-A$, we can conclude that a concentration of $10 \mu \mathrm{L} . \mathrm{mL}^{-1}$ of the extract has a lethal activity against $B$. subtilis. This is also true for a $5 \mu \mathrm{L} \cdot \mathrm{mL}^{-1}$ concentration of $\mathrm{MeOH}$ extract of $I A-M$ against $B$. subtilis.
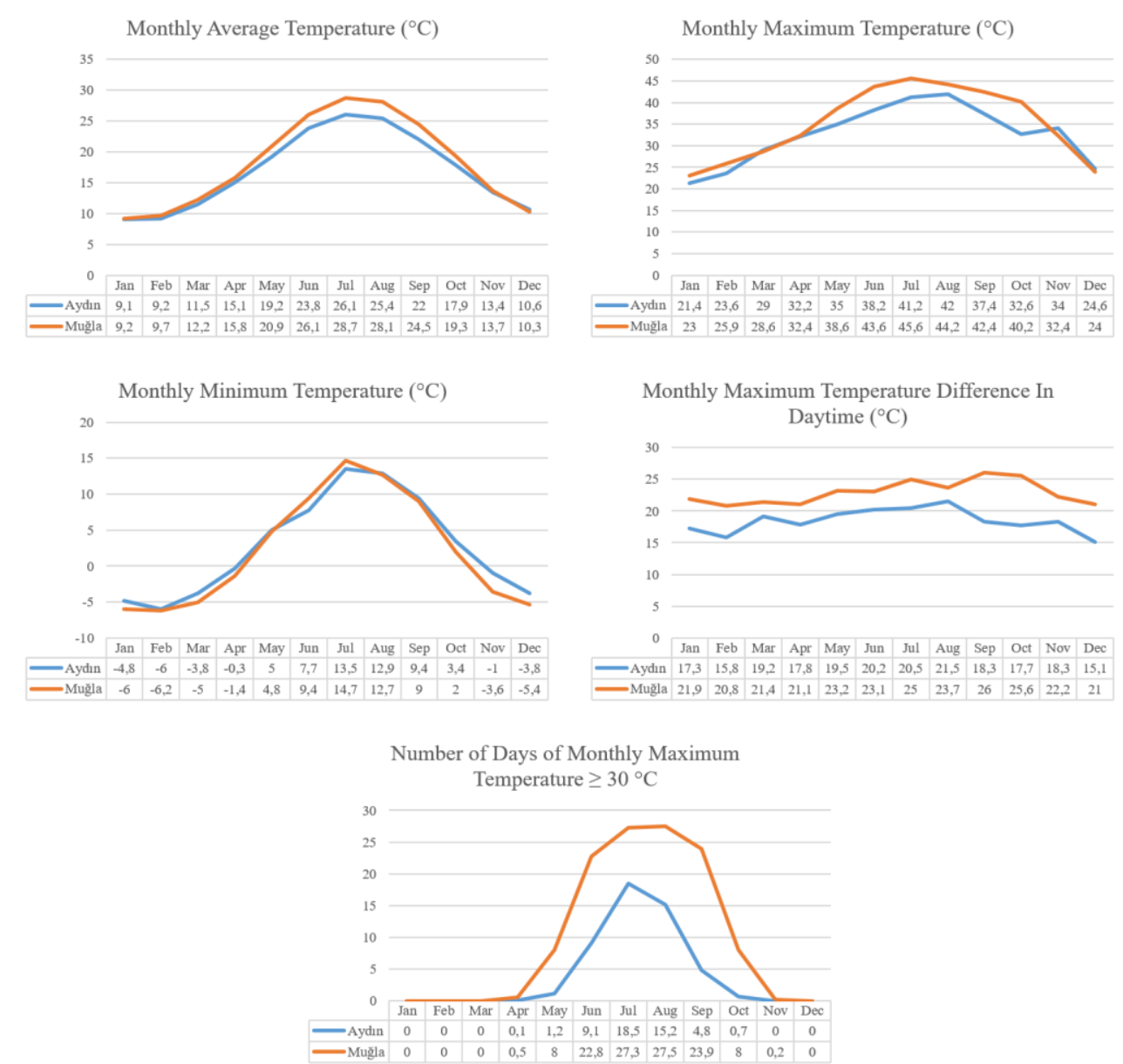

Figure 1 . Monthly temperature values 
A concentration of $40 \mu \mathrm{L} \cdot \mathrm{mL}^{-1}$ for both $\mathrm{MeOH}$ and $\mathrm{EA}$ extracts of $I A-M$ samples against $S$. aureus can be concluded to have a static type of activity, since the $M B C$ values are much higher than their $M I C$ values.

A concentration of $40 \mu \mathrm{L} . \mathrm{mL}^{-1}$ for both $C H L$ and $\mathrm{sdH}_{2} \mathrm{O}$ extracts of $I A-M$ samples against $E$. coli can be concluded to have a static type of activity, since the $M B C$ values are higher than their $M I C$ values. But concentrations of $40 \mu \mathrm{L} \cdot \mathrm{mL}^{-1}$ for $B E$ and $D E E$ of the same sample against $E$. coli have a lethal effect, since they have the same $M I C$ and $M B C$ values.

Buffer and $\mathrm{sdH}_{2} \mathrm{O}$ extracts of $I A-M$ samples presented antifungal activity against C. albicans and the activity of the $\mathrm{sdH}_{2} \mathrm{O}$ extract was very notable. A concentration of $0.625 \mu \mathrm{L} \cdot \mathrm{mL}^{-1}$ for this extract, which is a quite low concentration when compared to other extracts, shows a lethal effect against C. albicans, since the concentration for $M F C$ is equal to $M I C$ value.

Another aim of this study is to observe the effectiveness of several extraction solvents, such as $\mathrm{CHL}, \mathrm{BE}, \mathrm{DEE}, \mathrm{EtOH}, \mathrm{MeOH}, \mathrm{EA}$, $\mathrm{sdH}_{2} \mathrm{O}$ and a buffer. According to the results given in Table 1, the effect of extraction solvents on antimicrobial activity is very clear. Only $B E$ extraction of $I A-A$ has showed antimicrobial activity against $B$. subtilis, whereas the other extractions have no activity. The antimicrobial effect of $I A-M$ is very noteworthy when its activity is compared with $I A-A$. If the effect of $I A-M$ on $B$. subtilis is analysed, it can easily be observed that the $B E$ extraction of $I A-M$ has no activity against $B$. subtilis, but the $\mathrm{MeOH}$ extract of $I A-M$ has a higher activity against $B$. subtilis. In addition to B. subtilis, IA-M has an anti-microbial effect against $S$. aureus, $E$. coli and C. albicans too. Cowan has reviewed the solvents used for active compound extraction, and shows that different solvents dissolve different active substances (Cowan, 1999). This can also be explained by a well-known saying about solubility, which is "like dissolves like" (Kenneth, 1994). This means that a solute will dissolve best in a solvent having a similar chemical structure. The overall extraction capacity of a solvent primarily depends on its polarity. The difference between the anti-microbial effects of $I A-A$ and $I A-M$ can be explained by this. Due to different ecological conditions, different secondary metabolites could be synthesized in these two different $I A$ samples.

Different secondary metabolites synthesized according to different ecological conditions can also be the cause of the extra antimicrobial effects on more microorganisms in $I A-M$ extracts.

The main aim of this study is to put forward the effect of ecological conditions, mainly some meteorological conditions, on the antimicrobial activity of a bryophyte sample, which means to put forward the effect of these conditions on secondary metabolite metabolisms.

As Reeve mentioned (Reeve, 2005), climate is one element - that remains out of human control - which affects secondary metabolite production. It was also stated by Reeve (2005) that, in general, production of secondary metabolites, such as essential oils, is extremely dependent on the weather. So, to observe the effect of some meteorological conditions, several meteorological data were obtained from the Turkish State Meteorological Service.

The meteorological data have been organised into five groups. These are monthly temperature values, monthly soil temperature values, monthly precipitation values, monthly humidity values and monthly average daily total global sunshine values.

The monthly temperature values group contains data about monthly average temperature, monthly maximum temperature, monthly minimum temperature, monthly maximum temperature difference in daytime and number of days of monthly maximum temperature $\geq 30{ }^{\circ} \mathrm{C}$. The data for this group are given in Figure 1.

Figueiredo et al. (1997) stated that weather parameters related to temperature affect secondary metabolite production.

When monthly average temperatures of two locations given in Figure 1 were analysed, it can be seen that the differences in average temperatures between these two locations are significant, especially during 
June, July, August and September. This is also true when data relating to the number of days of monthly maximum temperatures $\geq 30$ ${ }^{\circ} \mathrm{C}$ were analysed.

During these four months the monthly average temperature of Muğla, where $I A-M$ samples were collected, is higher than in
Aydın, where $I A-A$ samples were collected. The difference between Aydın and Muğla in terms of monthly maximum temperature values is significant during June, July, August, September and October.

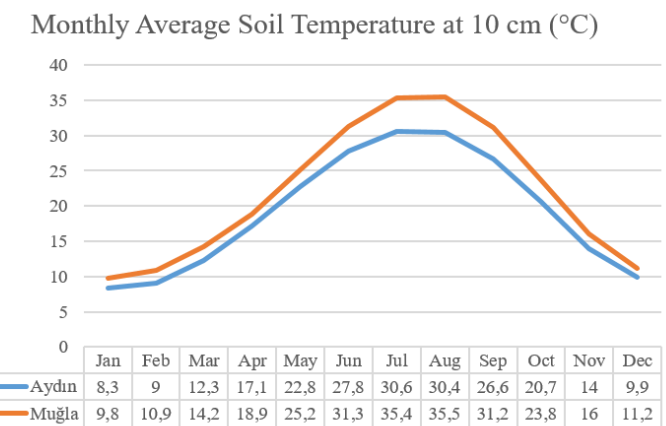

Monthly Average Maximum Soil Temperature at $5 \mathrm{~cm}\left({ }^{\circ} \mathrm{C}\right)$

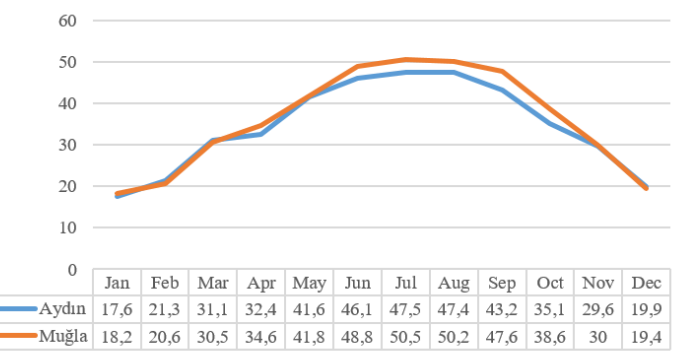

Monthly Average Minimum Soil Temperature at 5 $\mathrm{cm}\left({ }^{\circ} \mathrm{C}\right)$

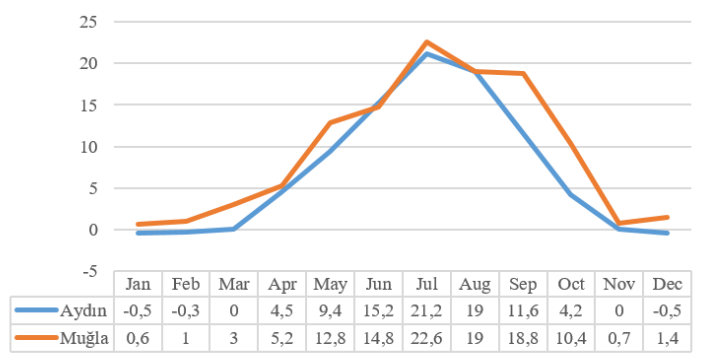
$10 \mathrm{~cm}\left({ }^{\circ} \mathrm{C}\right)$

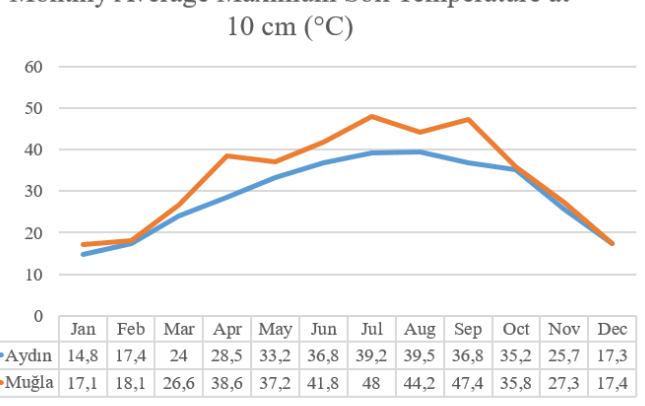

Monthly Average Minimum Soil Temperature at $10 \mathrm{~cm}\left({ }^{\circ} \mathrm{C}\right)$

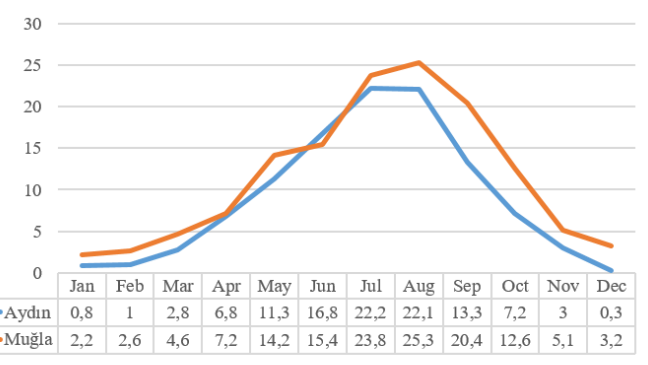

Monthly Average Number of Days of Temperature Above Soil $\leq-0.1^{\circ} \mathrm{C}$

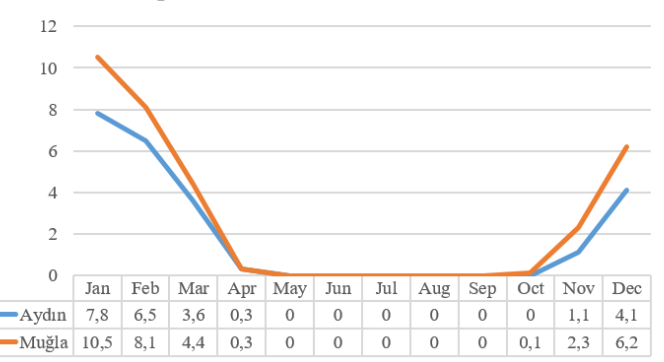

Figure 2. Monthly soil temperature values 
According to these values it can be concluded that Muğla has higher maximum temperatures than Aydin.

When monthly minimum temperature values are compared, it can be seen that Muğla has lower minimum temperature values than Aydin during December, January, February and March.

Lastly, when data for monthly maximum temperature differences in daytime were analysed - given in Figure 1 - it can be seen that the maximum temperature difference in daytime is higher in Muğla than in Aydın throughout the year.

As a conclusion of Figure 1, it can be stated that $I A-M$ samples were under more stress than $I A-A$ in terms of temperature values. When Table 1 and Figure 1 are compared it can be said that temperature stress could cause IA samples to synthesize more secondary metabolites.

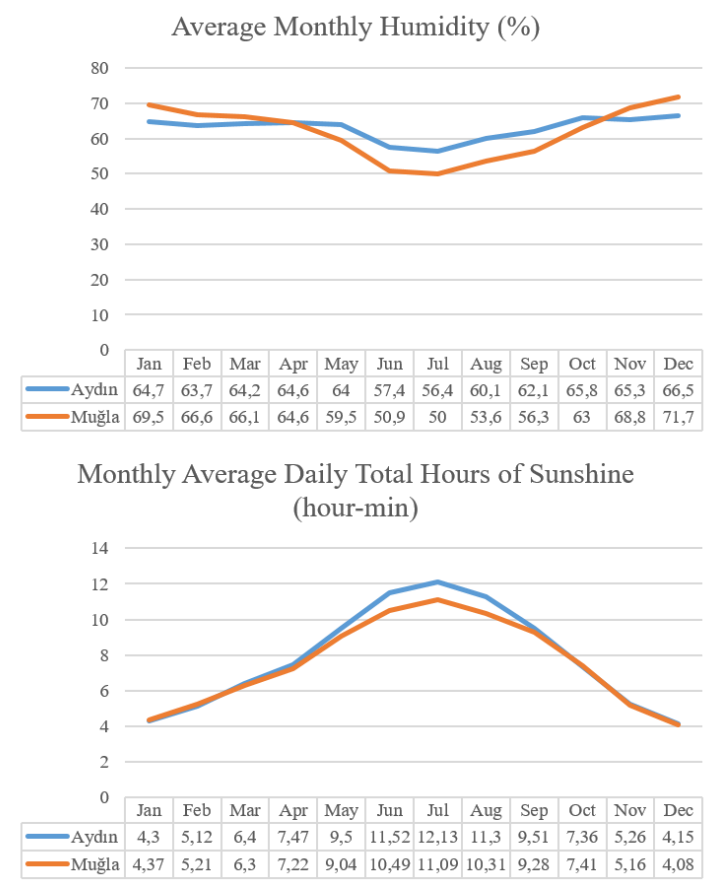

Figure 3. Monthly precipitation values, monthly humidity values and monthly average daily total global sunshine values

Thus, $I A-M$ is effective than $I A-A$ in terms of antimicrobial activity.

The monthly soil temperature values group contains:

- monthly average soil temperature at $5 \mathrm{~cm}$

- monthly average soil temperature at 10 $\mathrm{cm}$

- monthly average maximum soil temperature at $5 \mathrm{~cm}$

- monthly average maximum soil temperature at $10 \mathrm{~cm}$

- monthly average minimum soil temperature at $5 \mathrm{~cm}$

- monthly average minimum soil temperature at $10 \mathrm{~cm}$

- monthly average number of days of temperature above soil $\leq-0.1{ }^{\circ} \mathrm{C}$. 2.

The data for this group are given in Figure

When the data in Figure 1 and Figure 2 are compared, it can be seen that the soil temperature differences have an approximately similar tendency to that of the temperature differences between the two locations throughout the whole year.

According to the description of the $I$. alopecuroides species, it is stated that the height of the tallus is 2-6 centimetres (Atherton et al., 2010). Thus, the data for soil temperatures at $5 \mathrm{~cm}$ given in Figure 2 are the important data for $I A$ samples in terms of soil temperature values.

When the data in Figure 2 are compared, it can be concluded that $I A-M$ could be under 
more stress than $I A-A$, especially during June, July, August and September. Thus, there is more possibility that $I A-M$ samples synthesized more secondary metabolites due to soil temperature stress, which also supports the difference in the antimicrobial effect between $I A-A$ and $I A-M$ samples.

Figueiredo et al. (1997) stated that humidity also affects secondary metabolite production. When the data in Figure 3 are analysed, humidity in Muğla is lower than in Aydın, especially during May, June, July, August and September. These values can also support the difference in antimicrobial activity in $I A-A$ and $I A-M$.

The monthly average daily total global sunshine values contain monthly average daily total global sunshine intensity and monthly average daily total hours of sunshine. The data for this group are given in Figure 3.

Day length is another parameter which also affects secondary metabolite production (Figueiredo et al., 1997). Figure 3 can support information about how daily total global sunshine intensity and total hours of sunshine affect secondary metabolite production. Aydin has a longer day length and a higher global sunshine intensity when compared to Muğla.

Turtola et al. (2003) showed that under induced stress conditions of drought, the total amount of terpenes and resin acids increased, simultaneously, with a decrease in the growth of Pinus sylvestris and Picea abies seedlings. According to the results, it is also possible to accept that environmental stress also affects secondary metabolite production in lower plants, as shown in this study conducted by IA samples.

According to Figueiredo et al. (1997), among other effects, drought stress can limit photosynthesis in plants and alter nutrient uptake and carbon, sugar, amino acid and inorganic ion fluxes. When the data given in Tables 3, 4, 5, 6 and 7 are analysed it is obvious that the same stress proposed by Figueiredo et al. (1997) could affect IA samples.

As a result, it can be concluded that in any study based on secondary metabolites, the time and the environmental conditions where the plant samples are collected should be taken into account. In addition, since the substrates and altitudes of the samples were different, the effect of these parameters should also be analysed in further detailed research.

\section{Acknowledgement}

We would like to thank to Turkish State Meteorological Service for supporting meteorological data and Prof. Dr. Cumhur ÇÖKMÜŞ for his support and help during the study.

\section{References}

Altuner, E.M. (2011). Investigation of antimicrobial activity of Punica granatum L. fruit peel ash used for protection against skin infections as folk remedies especially after male circumcision. African Journal of Microbiology Research, 5(20), 3339-3342.

Altuner, E.M., Akata, I. (2010). Antimicrobial activity of some macrofungi extracts. Sakarya Üniversitesi Fen Bilimleri Enstitüsü Dergisi, 14(1), 45-49.

Altuner, E.M., Akata, I., Canl1, K. (2012a). In vitro antimicrobial screening of Bovista nigrescens (Pers.). Journal of Forestry Faculty of Kastamonu University, 12(1), 90-96.

Altuner E.M., Akata I., Canlı K. (2012b). In vitro antimicrobial screening of Cerena unicolor (Bull.) Murrill (Polyporaceae Fr. ex Corda). Fresenius Environmental Bulletin, 21(1B), 3704-3710.

Altuner, E.M., Canl1, K. (2012). In vitro antimicrobial screening of Hypnum andoi A.J.E. Sm. Journal of Forestry Faculty of Kastamonu University, 12(1), 97-101.

Altuner, E.M., Canl1, K., Akata, I. (2014). Antimicrobial Screening of Calliergonella cuspidata, Dicranum polysetum and Hypnum cupressiforme, Journal of Pure and Applied Microbiology, 8(1), 539-545.

Altuner, E.M., Çetin, B. (2009). Antimicrobial activity of Thuidium delicatulum (Bryopsida) extracts. Kafkas Üniversitesi Fen Bilimleri Enstitüsü Dergisi, 2(2), 85-92. 
Altuner, E.M., Çetin, B. (2010). Antimicrobial activity of Tortella tortulosa (Hedw.) Limpr. extracts. Kastamonu University Journal of Forestry Faculty, 10(2), 111-116.

Altuner, E.M., Çetin, B., Çökmüş C. (2010b). Antimicrobial screening of some mosses collected from Anatolia. Pharmacognosy Magazine, 6(22), 56.

Andrews, J.M. (2003). BSAC standardized disc susceptibility testing method (version 6). Journal of Antimicrobial Chemotherapy, 60(1), 20-41.

Atherton, I., Bosanquet, S. D., Lawley, M. (Eds.). (2010). Mosses and liverworts of Britain and Ireland: a field guide (p. 848). Plymouth: British Bryological Society.

Basile, A., Vuotto, M.L., Ielpo, T.L., Moscatiello, V., Ricciardi, L., Giordano, S., Cobianchi, R.C. (1998). Antibacterial activity in Rhynchostegium riparoides (Hedw.) Card. extract (Bryophyta). Phytotherapy Research, 12(S1), 146-148.

Canlı, K., Altuner, E.M., Akata, I. (2015). Antimicrobial screening of Mnium stellare, Bangladesh Journal of Pharmacology, 10(2), 321-325.

Canli, K., Altuner, E.M., Akata, I., Turkmen, Y., Uzek, U. (2016). In vitro antimicrobial screening of Lycoperdon lividum and determination of the ethanol extract composition by gas chromatography/mass spectrometry. Bangladesh Journal of Pharmacology, 11(2), 389-394.

Canlı, K., Çetin, B., Altuner, E.M., Türkmen, Y., Üzek, U., Dursun, H. (2014). In vitro antimicrobial screening of Hedwigia ciliata var. leucophaea and determination of the ethanol extract composition by Gas Chromatography/Mass Spectrometry (GC/MS). Journal of Pure and Applied Microbiology, 8(4), 2987-2998.

Cowan, M.M. (1999). Plant products as antimicrobial agents. Clinical Microbiology Reviews, 12(4), 564-582.

Croteau, R., Kutchan, T. M., \& Lewis, N. G. (2000). Natural products (secondary metabolites). Biochemistry and Molecular Biology of Plants, 24, 1250-1319.
Crozier, A., Clifford, M.N., Ashihara, H. (2006). Plant Secondary Metabolites: Occurrence, Structure and Role in the Human Diet. Blackwell.

Cseke, L. J., Kirakosyan, A., Kaufman, P. B., Warber, S., Duke, J. A., Brielmann, H. L. (2016). Natural products from plants. CRC Press.

Erdogrul, Ö.T. (2002). Antibacterial activities of some plant extracts used in folk medicine. Pharmaceutical Biology, 40(4), 269-273.

Figueiredo, A.C., Barroso, J.G., Pedro, L.G., Scheffer, J.J.C. (1997). Physiological aspects of essential oil production. Essential oils: Basic and Applied Research, 95-107.

Figueiredo, A.C., Barroso, J.G., Pedro, L.G., Scheffer, J.J. (2008). Factors affecting secondary metabolite production in plants: volatile components and essential oils. Flavour and Fragrance Journal, 23(4), 213-226.

Hammer, K.A., Carson, C.F., Riley, T.V. (1999). Antimicrobial activity of essential oils and other plant extracts. Journal of Applied Microbiology, 86(6), 985-990.

Jones, F.A. (1996). Herbs-useful plants. Their role in history and today. European Journal of Gastroenterology \& Hepatology, 8(12), 1227-1231.

Kenneth, L.W. (1994). Macroscale and microscale organic experiments. Lexington.

Lis- Balchin, M., Deans, S.G. (1997). Bioactivity of selected plant essential oils against Listeria monocytogenes. Journal of Applied Microbiology, 82(6), 759-762.

Makkar, H.P., Siddhuraju, P., Becker, K. (2007). Plant secondary metabolites. Humana Press.

Onbaşılı, D., Altuner, E.M., Çelik, G.Y. (2011). Antimicrobial activity of Mnium marginatum extracts. Kastamonu University Journal of Forestry Faculty, 11(2), 205-208.

Reeve, D. (2005). A Cultivated Zest, The lemon's origins, production and processing. Perfumer \& Flavorist, 30(3), $32-35$. 
Reynolds, J.E.F. (1996). Martindale - The Extra Pharmacopoeia. Royal Pharmaceutical Society of Great Britain.

Saroya, A.S. (2011). Herbalism, Phytochemistry and Ethnopharmacology. Herbal Consultant.

Turtola, S., Manninen, A.M., Rikala, R., Kainulainen, P. (2003). Drought stress alters the concentration of wood terpenoids in Scots pine and Norway spruce seedlings. Journal of Chemical Ecology, 29(9), 1981-1995.

Veljić, M., Tarbuk, M., Marin, P.D., Ćirić, A., Soković, M., Marin, M. (2008). Antimicrobial activity of methanol extracts of mosses from Serbia. Pharmaceutical Biology, 46(12), 871-875. 